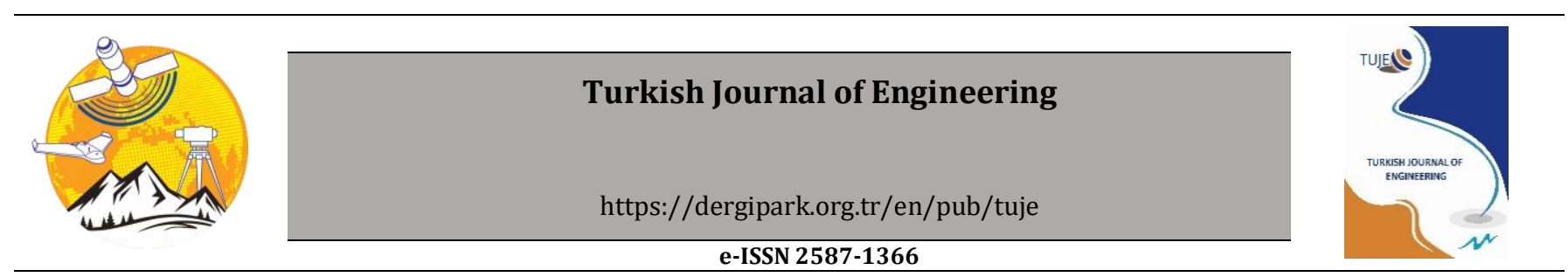

\title{
A study on effects of system thinking and decision-making styles over entrepreneurship skills
}

\author{
Huseyin Yener ${ }^{* 1}$ (D) \\ ${ }_{1}^{1}$ Maltepe University, Engineering Faculty, Industrial Engineering Department, Istanbul, Turkey
}

\author{
Keywords \\ Entrepreneurship Skills \\ System Thinking \\ Decision-Making Styles \\ Relational Screening Model
}

\begin{abstract}
Entrepreneurship has an uncertain environment requiring several abilities to achieve the goal. The article explores the effects of individuals' system thinking level, decision-making styles and family background on their entrepreneurial skills. In the study relational screening model is used as a research method. The sample group of the study consists of 65 students of the 4 th grade students of a private university in Istanbul, Turkey in 2019. Three questionnaires have been applied and descriptive statistics and all the other tests have been conducted by using SPSS 26 to examine the extent of involvement, significance, direction and degree of the relationships. The results show that there is a positive moderate significant $(r=0.542)$ relationship between individuals' entrepreneurship skill and system thinking level. Also a positive low level relationship $(r=0.374 \mathrm{p}<0.05)$ has been detected between entrepreneurship skills and vigilance type of decision-making style. Negative low level of relationships $(r=-0.123$ and $r=-0.244, p<0.05)$ among entrepreneurship skills, hypervigilance and procrastination types of decision-making styles. Moreover, no significant relationship has been found among entrepreneurship skills, parental education/job status and entrepreneurship experience/history in the family supporting the idea that entrepreneurship is a learnable skill rather than an innate skill.
\end{abstract}

\section{INTRODUCTION}

Economic and social challenges all around the world motivates the idea of developing more entrepreneurial activities. Entrepreneurship can be realized with individuals that can approach complex problems and events in a holistic framework and make the right decisions. Decision-making is to select the optimum one out of several options (Saaty, 2008). Individuals' innate abilities in decision-making process are very important and effective parameters. On the other hand, system thinking approach puts forward every action taken may or will have an effect on the other parts of a system. System thinking approach may give guidance individuals while they are producing solutions to the problems encountered. Besides, it is aimed to investigate whether the family experience and back-ground on entrepreneurship has an effect on both of these skills. In the literature, it is stated that "entrepreneurship, system thinking and decision-making are the features that can be developed with education" which should motivate education institutions to develop education programs to foster these abilities for our world's mutual benefits (Davidsson, 2006).

To reveal the interactions among family background, decision-making styles, system thinking on entrepreneurship skills, three questionnaires were applied to sample group and the results were analyzed in the application part of the study. Results of the study supported the idea that the entrepreneurship skill is not innate and can be improved by education activities. Similarly, it is found that there is a significant relation among entrepreneurship skills, system thinking and vigilance, hypervigilance and procrastination type of decision-making styles. No significant interaction with buck passing type of decision-making style was detected.

\subsection{Entrepreneurship Education}

Richard Cantillon, the father of entrepreneurial thinking, put forward the concept of entrepreneurial thinking in the 17th century against ambiguity (Patel and Mehta 2016). He defined entrepreneurship as selfemployment of any kind. Entrepreneurs buy in the present and sell at uncertain prices in the future

\footnotetext{
* Corresponding Author

*(huseyinyener@maltepe.edu.tr) ORCID ID 0000 - 0002 - 2152 - 5362
}

Cite this article

Yener H (2022). A study on effects of system thinking and decision-making styles over entrepreneurship skills. Turkish Journal of Engineering, 6(1), 26-33 
(Cantillon, 1775). The key term in his definition was ambiguity. Casson (2010) stated that "after about a century, Adam Smith described entrepreneurial thinking as a frugal and slow but steady progress agent for accumulating capital". However, Michaels (2012) explained in his study that "entrepreneurship can be thought like any other subject. Above all, entrepreneurial thinking is a mindset that emphasizes learning about the opportunity and making use of the situation in a unique way".

For this reason, Henry et al. (2003) put forward that "education and training programs constitutes a major role in training future entrepreneurs and developing the skills of existing entrepreneurs". Gibb (1987) stated that "although the entrepreneurship has cultural and experimental portions, it can be improved gradually by education". Traditional entrepreneurship carries risks (McGrath, 1995; McGrath, 2000). Therefore, it is necessary to make the right decision for successful entrepreneurship. For the right decision, system thinking skills are needed, which allow to look at the events and problems from multiple perspectives. Entrepreneurship education is considered as an education model to change attitudes, trends and motivations.

Studies report that the traditional entrepreneurship approach should change. According to this understanding, entrepreneurship should be developed with new education and training techniques. Among these techniques, the development of thinking skills, mentoring and group work are widely accepted. Implementation is required for project management and development of budget skills. Therefore, according to Kalyani and Kumar (2011) "it is increasingly recognized that teaching entrepreneurship skills should include interactive teaching requiring skillful instructors".

Whether or not entrepreneurship is innate is a controversial issue. Despite common view that entrepreneurs are innate, there are also the other studies claiming entrepreneurship is a skill to learn. Drucker (1985) described that "entrepreneurship is a discipline and has been reported to be learnable like any other discipline". According to this view, it is necessary to review the entrepreneurship trainings given at universities in the training of entrepreneurial individuals, including active methods.

According to Gibb (2011), the entrepreneurship education needs to be changed since the traditional entrepreneurship model can no longer be applied to the modern business environment. Entrepreneurship education is emphasized more by the relevant field experts Berglund and Wennberg (2006), Patır and Karahan (2010) which are important for the factors that determine entrepreneurship. It is stated that entrepreneurship education increases individuals' chances of becoming a successful entrepreneur, increases the level of knowledge by developing understanding and awareness of entrepreneurship, and promotes positive attitude and tendency. This understanding emphasizes the understanding that entrepreneurs are not born and that they are prone to education. Entrepreneurship education draws attention to the view that it supports young entrepreneur candidates to reveal entrepreneurial potential and encourages them to start their own businesses (Guzmán and Liñán 2005). All these research results point out entrepreneurship training to be provided at various educational levels and types starting from an early age in developing entrepreneurship trends. In this sense, big tasks fall for the decision-makers on the subject in terms of effective policies they will produce to realize them.

Entrepreneurship is the power of economy, the source of discovery and imagination. In countries where there is no entrepreneurship or insufficiency, the level of economic welfare is low (Mueller, 2011). The rapid increase in globalization and competition, the inability of governments to provide appropriate funds for higher education, the increase in the need for qualified manpower and many other factors require universities to turn into an entrepreneurial structure (Greenspan and Rosan 2006).

\subsection{System Thinking Skills}

System thinking can be defined as an approach for examining and understanding complex problems from a holistic perspective (Orgill et al., 2019). Evagorou et al. (2009) described system thinking as "a method of seeing systems from a broad perspective". Dori and Sillitto (2017) stated in their study that "complexity decisionmaking, especially with holistic or system approach. The holistic approach of system thinking is claimed to improve the quality of decision processes". The system provides communication and collaboration with a holistic perspective on the basis of thinking. System thinking has been reported to be effective in giving a holistic perspective to a problem. The basic idea behind the system thinking to break down the whole into sub elements and study the interactions of elements (Patel and Mehta 2016).

To understand the system thinking, first thing is to define the system. System; is a group that consists of interdependent and interconnected units, consisting of different sections and established according to a general plan, and is oriented towards the purpose to achieve a certain result. Systems in engineering are fundamental, and natural events in science can be defined as systems. In engineering, systems are grouped into three subcategories: function (benefit), structure (form) and behavior (dynamics) (Dori and Sillitto 2017) System thinking is a systematic evaluation of understanding the situation, taking into account of system perspective (Assaraf and Orion 2005).

According to Long (2012) "in engineering, design and system thinking can be used together. System thinking is sometimes described as a component of design thinking". Scientists have emphasized the importance of system thinking approach in entrepreneurship education (Forrester, 2007). System thinking is necessary to increase the ability of societies to understand the system, find to the problems encountered bearing in mind the side effects of the solutions. Verhoeff et al., (2008) revealed that "system thinking ability is accepted as a higher level of thinking skill that is essential for understanding concepts and principles in science and engineering". It has been reported that system thinking skills are necessary for understanding complex events 
and solving complex problems. In addition, it has been explained that thinking of the system requires more than innovation and entrepreneurship skills (Evagorou et al., (2009).

\subsection{Decision-Making Styles}

Everybody gives many decisions every time in his or her daily life. Some of them lead desired results, some of the others give undesirable results (Haan, 2010). Generally, decision-making includes a group of people or organizations rather than a person. Sustainable development means prosperity for today's society and future generations. Today, problems faced for sustainability development are quite complex. In order to solve these complex problems, decision-making and problems must be viewed from multiple perspectives (Arvai et al., 2004). Engineering can be considered as a complex process that consists of a successive decisions and does not compromise (Hernandez et al., 1998). Today's ambiguous and complex environment necessitates people and organizations to make better decisions to maintain competitive advantage.

Interdisciplinary approaches are important in educational activities, as real-world decisions often involve more than one area (Solomon and Aikenhead, 1994). From this perspective, students need to be equipped with more skills before entering the labor market or industrial society. However, in educational institutions, students are not properly equipped to solve and decide on disciplinary problems such as sociological issues, engineering and design skills (Zeidler et al., 2009). Scientific decision-making is important in developing students' learning abilities, scientific literacy, conceptual understanding, scientific research, attitude and social values. Sadler and Zeidler (2005) stated that "rapid changes are created in our lives with science. In order to keep up with this speed, rational thinking and information technology of learners should be equipped with the decision-making abilities".

Saaty (2008) divides decision-making processes into two, intuitively and analytically. Intuitive decisions are not supported by data and are generally made arbitrarily. In some simple, depth-free decision situations, the intuitive approach can be successful. However, when faced with complex decision situations requiring information, decision makers can see that their decisions ultimately deviate from their own value judgments. Contrary to what has been believed for a long time nowadays, it has become a "science" rather than an "art". Yesilyaprak (2003) expressed that "decision-making activity is affected by both emotional and cognitive features". Decision-making style affects a person's approach, reactions and actions in a decision-making process (Thunholm, 2009).

Today, companies have seen innovation as an imperative to survive in competitive environments. Entrepreneurship and decision making skills are very important for the development of innovation (Gelderen and Masurel 2012). Although there are important studies on the development of these skills in the literature, there are no studies examining them all together.

\section{MATERIALS AND METHOD}

\subsection{The Second Level Headings}

The main problem of the study constitutes the question; Is there a relationship among entrepreneurship skills, system thinking and decisionmaking styles? The sub-problems are defined as below:

1. Is there a relationship between entrepreneurship skills and system thinking levels?

2. Is there a relationship between entrepreneurship skills and decision-making styles?

3. Is there a relationship between system thinking levels and decision-making styles?

4. Is there a relation between entrepreneurship skills and parents' education levels?

5. Is there a relationship between entrepreneurship skills and parents' jobs?

6. Is there a relationship between entrepreneurship skills and families' entrepreneurship history or experiences?

\subsection{Model of the Research}

In the study relational screening model was used as research method. The screening model is all of the processes that describe a situation as it exists in the past or present, and is applied to realize learning and to develop desired behaviors in the individual. In the general screening model, in a universe consisting of a large number of elements, in order to make a general judgment about the universe, the entire universe or a group of samples to be taken from it is scanned. The relational screening model aims to put forward the existence of co-variation among parameters. The goal of this study is to investigate the impact levels of family history and experiences about entrepreneurship, decision-making stiles and system thinking levels on individuals' entrepreneurship skills.

\subsection{Study Group}

Sample group of the study consisted of 65 students of the 4 th grade students of a university in Istanbul, Turkey in 2019. In experimental studies it is advised that the sample group shall be at least 30 (Gay, 1996) which sample size of the study meets criterion. Students in the study group were selected on a voluntary basis.

\subsection{Data Collection Tools}

\subsubsection{Entrepreneurship questionnaire}

In the study, a 25-item entrepreneurship questionnaire developed by Kashif et al. (2016) was used to determine the level of entrepreneurship. Five-point Likert-type questionnaire was used. There are no inverse questions in the test. Cronbach's alpha coefficient was determined by using SPSS as $0.89(\mathrm{~N}=100)$ for the reliability of the questionnaire (Kashif et al., 2016).

\subsubsection{System thinking skill questionnaire}

A 20-item questionnaire developed by Moore et al. (2010) to test system thinking skill. Five-point Likert- 
type questionnaire was used. There are no inverse questions in the test. reliability and validity were assessed. Moore et al. (2010) conducted test and retest reliability evaluation $(n=36)$ resulting a correlation of 0.74 and internal consistency testing $(n=342)$ Cronbach's alpha coefficient of 0.89 .

\subsubsection{Decision-making styles questionnaire}

Decision-making styles were tested by "Melbourne Decision-Making Questionnaire" developed by Mann et.al (2014). The scale has 22 items and measures decision-making styles. It has 4 sub-scales as "Vigilance type of decision-making", "Hypervigilance type of decision making", "Procrastination type of decisionmaking" and "Buck Passing type of decision-making". Validity and reliability of the questionnaire were tested by Deniz (2004). Content validity was performed using similar scales validity method and expert opinion was consulted. Reliability of the questionnaire was calculated by repetition of the questionnaire and internal consistency methods. The repetition of the questionnaire was applied to 56 university students twice at threeweek intervals and reliability coefficients were between $r=0.68$ and $r=0.87$. Internal consistency coefficients of the test applied to 154 university students were calculated as; vigilance type 0.80 , hypervigilance type 0.78 , procrastination type 0.65 and buck passing type 0.71 .

\subsection{Data Analysis}

Entrepreneurship questionnaire, was organized with a 5-point Likert-type rating and consisted of 25 questions. Scale was calculated as "Most of the Time" (4 points), "Often" (3 points), "Some of the time" (2 points), "Seldom" (1 point) and "Never" (0 point). Total number is computed by adding up the points for each question. It can range from 0 to 100 .

System thinking skill questionnaire was organized with a 5-point Likert-type rating and consisted of 20 questions. Scale was calculated as "Most of the Time" (4 points), "Often" ( 3 points), "Some of the time" ( 2 points), "Seldom" (1 point) and "Never" ( 0 point). Total number is computed by adding up the points for each question. It can range from 0 to 80 .

Decision-making styles questionnaire has 4 subscales. It is organized with a 3-point Likert-type rating and consisted of 22 questions. Scale was calculated as "Right" (2 points), "Sometimes Right" (1 point), "Not Right" (0 point).

Vigilance Type of Decision-Making: It is the situation where the individual searches the necessary information carefully before giving a decision and makes a selection after carefully judging all the alternatives. It is expressed in six items $(1,2,3,4,5,6)$ in the questionnaire.

Hypervigilance Type of Decision-Making: is the situation where the individual refrains from making decisions, lets the giving decision to others, and therefore tries to avoid the decision by transferring responsibility to someone else. This factor is expressed in six items (7, $8,9,10,11,12$ ) in the questionnaire.

Procrastination Type of Decision-Making: It is the state of the individual to postpone the decision, delay it and drag it without an acceptable reason. It is expressed in five items $(13,14,15,16,17)$ in the questionnaire.

Buck Passing Type of Decision-Making: When an individual is confronted with a decision situation, he or she feels hasty behavior under time pressure and tries to reach fast answers. It is expressed in five items $(18,19$, $20,21,22$ ) in the questionnaire.

\section{RESULTS}

In this study, test results are given in the tables below.

Table 1-3 contain information about the individuals' family background information. These data were used to reveal the individuals' family background and experience over their entrepreneurship skills.

According to Table 4, the reliability coefficient of the entrepreneurship questionnaire is 0.703 ; The reliability coefficient of the Melbourne decision-making styles questionnaire was 0.815 and the reliability coefficient of the system thinking questionnaire was found as 0.707 . The reliability coefficient of 0.70 and above indicates that the measurement tool used is reliable and has internal consistency between items (Nunnally and Bernstein 1994).

Normality analysis test results of the questionnaires at $95 \%$ confidence interval, it was understood that the data showed normal distribution characteristics. Then tTests were conducted to understand whether there are significant relationships among them for each of the subproblem questions of the study.

According to $\mathrm{t}$ - test results for mother education status, father education, mother job status and father job status shown in Table 5 since all p, sig. (2-tailed) values are larger than $\mathrm{p}=0.05$, it is understood that there is no significant relationship between university students' entrepreneurship skills and their parents' education and job status (sub-problem 4 and 5). It is not needed to apply further correlation tests to this category. Similarly, according to the results about family entrepreneurship experiences or history shown in Table 5, since p, sig. (2tailed) $=0.018$ value is less than $p=0.05$, it is understood that there is a significant relationship between university students' entrepreneurship skills and family entrepreneurship experiences (sub-problem 6).

The results of Table 5 for system thinking indicated that there is a significant relation between individuals' system thinking and entrepreneurship skills (subproblem 1 ) with the statistics of $p$ value, sig. (2-tailed $)=$ 0.004 .

When the t-test results for four types of decisionmaking styles in Table 5 are analyzed, it is understood that there is a significant relationship among students' entrepreneurship skills, system thinking levels, vigilance, hypervigilance and procrastination types of decisionmaking styles (sub-problem 2 and 3 ) because p, sig. (2tailed) values are found as $0.042,0.024$ and 0,036 lower than $\mathrm{p}=0.05$ respectively. However, there is no significant relation between students' entrepreneurship skills and buck passing type of decision-making style since $p$, sig. (2-tailed) $=0.334$ value is greater than $p=$ 0.05 . 
According to the correlation analysis test results shown in Table 6, a significant medium-level relationship was found between system thinking level and entrepreneurship skill ( $\mathrm{r}=0.542, \mathrm{p}<0.05)$. This relationship is important to understand the interaction between system thinking level and entrepreneurship skill respectively.

Similarly, when Table 6 is examined for entrepreneurship skill and decision-making styles, a positive low level relationship $(r=0.374$ and $r=0.225$, $p$ $<0.05$ ) was detected between university students' entrepreneurship skills and vigilance type of decisionmaking style. A positive relationship between vigilance type of decision-making and entrepreneurship skill refers to an expected situation. However, negative low level relationship $(r=-0.123$ and $r=-0.244, p<0.05)$ among individuals' entrepreneurship skills, hyper vigilance and procrastination types of decision-making styles were found this situation is reasonable as entrepreneurship relies on taking risks, being courageous and taking initiative naturally. Relationship with buck passing decision-making style was found as insignificant.

When the results of Table 6 are analyzed for system thinking and decision-making styles, a moderate positive correlation $(r=0.403, p<0.05)$ was detected between the system thinking ability and vigilance decision-making style. This can be interpreted as if a person has a high level of system thinking skill then he /she may also have a careful(vigilance) decision-making style and vice versa. The other types of decision-making styles were found insignificant.

Table 1. Parent education status

\begin{tabular}{lll}
\hline \multicolumn{3}{c}{ Education Status } \\
\hline Primary & $\begin{array}{l}\text { High } \\
\text { School }\end{array}$ & University \\
\hline 39 & 59 & 32 \\
\hline
\end{tabular}

Table 2. Parent job status

\begin{tabular}{lllll}
\hline \multicolumn{5}{c}{ Job Status } \\
\hline Unemployed & Freelancer & Public & Private & Retired \\
\hline 44 & 35 & 28 & 15 & 8 \\
\hline
\end{tabular}

Table 3. Entrepreneurship Experience in the Family Family Entrepreneurship Experience / History

\begin{tabular}{ll}
\hline Yes & No \\
\hline 14 & 51 \\
\hline
\end{tabular}

Table 4. Cronbach's alpha values resulted from the reliability analysis of the questionnaires

\begin{tabular}{lll} 
& Item Number & Cronbach alpha coefficient \\
\hline Entrepreneurship Questionnaire & 25 & 0.703 \\
Melbourne Decision Making Questionnaire & 22 & 0.815 \\
System Thinking Skill Questionnaire & 20 & 0.707 \\
\hline
\end{tabular}

Table 5. t-Test results

\begin{tabular}{|c|c|c|c|c|}
\hline Variables & $\mathrm{N}$ & $\bar{X}$ & Ss & $\mathrm{P}^{*}$ \\
\hline \multicolumn{5}{|l|}{ Family Background } \\
\hline Mother Education Status & 65 & 84.636 & 6.028 & 0.708 \\
\hline Father Education Status & 65 & 84.275 & 6.204 & 0.795 \\
\hline Mother Job Status & 65 & 83.909 & 7.082 & 0.693 \\
\hline Father Job Status & 65 & 84.586 & 5.292 & 0.271 \\
\hline Family Entrepreneurship Experiences & 65 & 86.785 & 3.786 & 0.018 \\
\hline \multicolumn{5}{|l|}{ System Thinking } \\
\hline System Thinking Levels & 65 & 84.107 & 6.307 & 0.004 \\
\hline \multicolumn{5}{|l|}{ Decision-Making Styles } \\
\hline Vigilance Decision-Making Style & 65 & 10.153 & 1.864 & 0.042 \\
\hline Hypervigilance Decision-Making Style & 65 & 3.830 & 2.982 & 0.024 \\
\hline Procrastination Decision-Making Style & 65 & 4.230 & 2.691 & 0.036 \\
\hline Buck Passing Decision-Making Style & 65 & 5.246 & 6.920 & 0.334 \\
\hline
\end{tabular}
$* \mathrm{p}<0,05$

Table 6. Correlation analysis test results

\begin{tabular}{lll}
\hline Variables & $\mathrm{N}$ & $\mathrm{r}^{*}$ \\
\hline Entrepreneurship Skills vs System Thinking Levels & 65 & 0.542 \\
Entrepreneurship Skills vs Family Entrepreneurship Experiences & 65 & -0.224 \\
Entrepreneurship Skills vs Vigilance Decision-Making Style & 65 & 0.374 \\
Entrepreneurship Skills vs Hypervigilance Decision-Making Style & 65 & -0.123 \\
Entrepreneurship Skills vs Procrastination Decision-Making Style & 65 & -0.244 \\
Entrepreneurship Skills vs Buck Passing Decision-Making Style & 65 & - \\
System Thinking Level vs Vigilance Decision-Making Style & 65 & 0.403 \\
System Thinking Level vs Hypervigilance Decision-Making Style & 65 & - \\
System Thinking Level vs Procrastination Decision-Making Style & 65 & - \\
System Thinking Level vs Buck Passing Decision-Making Style & 65 & - \\
\hline
\end{tabular}




\section{CONCLUSION AND DISCUSSION}

In this study, the relationships among entrepreneurial skills, system thinking level, decisionmaking styles and family education status, the presence of entrepreneurial history/experience in the family were examined.

\subsection{Entrepreneurship and System Thinking}

When the findings obtained in the study are analyzed, it is determined that there is a positive medium-level significant $(r=0.542)$ relationship between entrepreneurship skill and system thinking level. This shows that the more system thinking ability increases, the more entrepreneurship ability increases. It can be deducted that the development of any of the training activities will affect the other reciprocally.

It is stated in the literature that system thinking skills are effective in developing entrepreneurship skills. Today, problems have become increasingly complex. System thinking skills that require interdisciplinary, holistic and in-depth thinking come to the fore in solving these complex problems (Pagani and Otto 2013). Carlman et al.,2014 stated that "holistic approach also increases the quality of decision processes in entrepreneurship". While making the system thinking approach, the decision-making process will help make the right decisions in turbulent and crisis environments. In order to develop entrepreneurship skills of individuals, it is recommended to use system thinking methods that encourages problem solving and innovation, from active learning methods (Hall et al., 2002; Pappas et al., 2012; Freeman et al., 2014).

Interdisciplinary approaches are important in educational practices; as real-world decisions often involve more than one area. From this perspective, individuals need to be equipped with more skills before entering the labor market or industrial society. However, in educational institutions, students are not properly equipped to solve and decide on interdisciplinary problems such as life-based sociological issues, engineering and design skills (Zeidler et al., 2009). Sadler and Zeidler (2005) stated that "rapid changes are created in our lives with science. In order to keep up with this speed, rational thinking and information technology of learners should be equipped with the ability to make decisions based on the data".

\subsection{Entrepreneurship and Decision-Making Styles}

According to the data obtained, while there was a significant relationship among vigilance, hypervigilance and procrastination decision-making styles; In the buck passing decision-making style, no significant relationship was found. A low-level positive correlation $(r=0.374, p$ $<0.05$ ) was detected between entrepreneurship skill and vigilance type of decision-making style. Studies have reported that it provides practical information on how to take advantage of effective decision-making processes in entrepreneurship (Rayawan and Efrata 2017). Sustainable development means prosperity for today's society and future generations. The problems faced by entrepreneurs for sustainable development are quite complex. In order to solve these complex problems, decision-making and problems should be viewed from multiple perspectives (Haan, 2010; Arvai et al., 2004). Scientific decision-making is important in developing individuals' learning abilities, scientific literacy, conceptual understanding, scientific research, attitude and social values.

\subsection{Entrepreneurship Skills and Family Background}

After the tests, no significant relationship between entrepreneurship skill and parental education/job status was found. This result was interpreted as the education and work status of the family have no effect on entrepreneurship skill. This indicates that individuals may have entrepreneurial skills independent of their families' socio-demographic and occupational status. It gives the opportunity to develop entrepreneurial skills through education. According to the results, a significant opposite low-level ( $\mathrm{r}=-0.224)$ relationship was found between entrepreneurship skill and family entrepreneurship experience. In order to explain this situation, the questionnaire questions were re-examined and it was understood that unsuccessful entrepreneurship experiences were frequently expressed in the free texts written by the participants and this situation might have caused this negative relationship.

In the literature review, it has been reported that entrepreneurship education is more important than the features that come from the family, which is a traditional approach of developing entrepreneurship. These results indicate that, depending on the entrepreneurship training received, entrepreneur candidates' attitudes towards entrepreneurship, perceptions of convenience and feasibility to become entrepreneurs, and thus entrepreneurship tendencies can increase positively. According to Korkmaz, (2012), entrepreneurship education is stated to be one of the most important factors especially in the formation of attitudes and behaviors of young entrepreneur candidates towards becoming entrepreneur. Matlay, (2008) determined that "entrepreneurship education had a positive effect on the individual's tendency towards entrepreneurship and increased it significantly". Some researches like Mueller (2011), Fayolle and Gailly 2013 and Miller et al., 2009 indicated that "there is a positive and significant relationship between entrepreneurship education and entrepreneurship tendency and sub-dimensions, supporting the results obtained from this research". Graevenitz et al. (2010) suggested that "to start at an early age in developing entrepreneurial skills".

With the assessment of entrepreneurship as a discipline, the view that entrepreneurship is innate has changed and the view of entrepreneurship through education has started to be accepted. Drucker (1985) reported that "entrepreneurship is not a magic, a mystery, it is a subject and can be learned". This judgment reached on entrepreneurship has changed the perspective and stated the opinions that entrepreneurship education can be done (Kuratko 2003). In line with the ideas that entrepreneurship is 
learnable, research and studies on entrepreneurship education have started.

As a result; Today's global environment, forces everybody to take steps toward developing entrepreneurial skills at every level to sustain competitive advantage in the business environment. Entrepreneurship, system thinking skills and decisionmaking processes are very important for the development of innovation. It is recommended to include active teaching programs for the development of these three skills in universities and the other institutions. A future study will be useful to compare with initial results after completing entrepreneurship and system thinking education. New studies on entrepreneurship, system thinking skills and decision-making styles in the covid-19 pandemic period may be helpful to understand the interactions among them better in telecommuting and elearning environment.

\section{Conflicts of interest}

The authors declare no conflicts of interest.

\section{REFERENCES}

Arvai J L, Campbell V E A, Baird A \& Rivers L (2004). Teaching students to make better decisions about the environment: lessons from the decision sciences. The Journal of Environmental Education, 36(1), 33-44.

Assaraf O B Z \& Orion N (2005). Development of system thinking skills in the context of earth system education. Journal of Research in Science Teaching, 42(5), 518-560. DOI: 10.1002/tea.20061

Berglund H \& Wennberg K (2006) Creativity among entrepreneurship students: Comparing engineering and business education. International Journal of Continuing Engineering Education and Life-long Learning. 16 (5), 366-379.

Cantillon R (1775). Essay on the nature of trade in general, London.

Carlman I, Grönlund E \& Longueville A (2014). Models and methods as support for sustainable decisionmaking with focus on legal operationalization. Ecological Modelling, 306, 95-100

Casson M C (2010). Entrepreneurship: Theory, Networks, History. Edward Elgar: Cheltenham, U.K.

Davidsson P (2006). Nascent entrepreneurship: Empirical studies and developments. Foundations and Trends in Entrepreneurship, 2 (1), 1-76.

Deniz M E (2004). Investigation of the relation between decision self-esteem, decision making style and problem solving skill of the university students. Eurasian Journal of Educational Research, 4(15), 2335.

Dori D \& Sillitto H (2017). What is a system? An ontological framework. Systems Engineering, 20 (3), 207-219.

Drucker P F (1985). Innovation and entrepreneurship. New York, NY: Harper \& Row.

Evagorou M, Korfiatis K, Nicolaou C \& Constantinou C (2009). An investigation of the potential of interactive simulations for developing system thinking skills in elementary school: a case study with fifth-graders and sixth graders. International. Journal of Science Education 31, 655-674. DOI: 10.1080/09500690701749313

Fayolle A \& Gailly B (2013). The impact of entrepreneurship education on entrepreneurial attitudes and intention: Hysteresis and persistence. Journal of Small Business Management, 53(1), 75- 93.

Forrester J W (2007). System Dynamics - a personal view of the first fifty years. System Dynamics Review, 23(23), 345-358.

Freeman S, Eddy S L, McDonough M, Smith M K, Okoroafor N \& Jordt H (2014). Active learning increases student performance in science, engineering, and mathematics. Proceedings of National Academy of Sciences of the United States of America, 111(23), 8410-8415.

Gay L R (1996). Educational research: Competencies for analysis and application. 5. Edition, Prentice-Hall, Inc., USA.

Gelderen M V \& Masurel E (2012). Entrepreneurship in context. Routledge, New York

Gibb A (1987). Enterprise Culture - Its Meaning and Implications for Education and Training. Journal of European Industrial Training, 11(2), 2-38

Gibb A (2011). Concepts into practice: meeting the challenge of development of entrepreneurship educators around an innovative paradigm. International Journal of Entrepreneurial Behaviour \& Research 17(2), 146-165.

Graevenitz G V, Hardoff D \& Weber R (2010). The effects of Entrepreneurship Education. Journal of Economic Behavior Organization, 76, 90-112.

Greenspan A \& Rosan R M (2006). The Role of Universities Today: Critical Partners in Economic Development and Global Competitiveness. http://www.icfconsulting.com/Markets/Community _Development/docfiles/role-niversities.pdf, [Accessed 30.12.2019].

Guzmán J Y \& Liñán P (2005). Perspectives on Entrepreneurial Education: A US-Europe Comparison. Jean Monnet European Studies Centre Universidad Antonio de Nebrija

Hall S R, Waitz I, Brodeur D R, Soderholm D H \& Nasr R (2002). Adoption of active learning in amlecturebased engineering class. In 32nd Frontiers in education conference, T2A-9. https://doi.org/10. 1109/fie.2002.1157921.

Haan G (2010). The development of ESD-related competencies in supportive institutional frameworks. International Review of Education, 56(2-3), 315-328.

Hernandez G, Allen J \& Mistree F (1998). ApproxımateCooperative Design Formulations for Enterprise Design and Integration. Proceedings of Detc98/Dac. Asme Design Engineering Technical Conference September 13-16, Atlanta, GA

Henry C, Hill F \& Leitch C (2003). Entrepreneurship Education and Training: The Issue of Effectiveness. Ashgate Publishing Ltd., London.

Kalyani B P R \& Kumar D M (2011). Motivational factors, entrepreneurship and education: Study with reference to women in SMEs. For East Journal of Psychology and Business, 3(3), 14-35. 
Kashif M, Darain H, Islam S, Javed S \& Irshad S (2016). Entrepreneurial Aptitude among the University Students of MBBS, BDS and DPT. Indian Journal of Physiotherapy and Occupational Therapy, 10(1), 6670

Korkmaz $O$ (2012). Üniversite öğrencilerinin girișimcilik eğilimlerini belirlemeye yönelik bir araștırma: Bülent Ecevit Üniversitesi örneği. Afyon Kocatepe Üniversitesi İBF Dergisi. XIV (II), 209-226.

Kuratko D (2003). Entrepreneurship Education: Emerging Trends and Challenges for the 21st Century: From Legitimization to Leadership. Coleman Foundation White Paper Series.

Long C (2012). Teach Your Students to Fail Better with Design Thinking. Learning \& Leading with Technology, 9(5), 16-20.

Mann L M, Radford P, Burnett S, Ford M, Bond K, Leung H, Nakamura G \& Malindi M M (2014). Impact of Entrepreneurship Education on Entrepreneurial Intent at Further Education and Training (FET) Colleges in South Africa. Gordon Institute of Business Science. University of Pretoria, $M B A$.

Matlay $H$ (2008). The impact of entrepreneurship education on entrepreneurial outcomes. Journal of Small Business and Enterprise Development, 15(2), 382-396.

McGrath R G \& MacMillan L C (1995). Discovery Driven Planning." Harvard Business Review, 73, 44-54.

McGrath R G \& MacMillan I C (2000). The entrepreneurial mindset: Strategies for continuously creating opportunity in an age of uncertainty (Vol. 284). Harvard Business Press.

Michaels C (2012). Essentials of Entrepreneurial Thinking: What Successful People Didn't Learn in School. Amazon. Published by cliff Michaels and associated Inc. Santa Monica. USA.CA (www.CliffMichaels.com)

Miller B K, Bell J D, Palmer M \& Gonzalez A (2009). Predictors of entrepreneurial intentions: A quasiexperiment comparing students enrolled in introductory management and entrepreneurship classes. Journal of Business \& Entrepreneurship, 21 (2), 39-62.

Moore S M, Dolansky M A, Singh M, Palmieri P \& Alemi F (2010). The Systems Thinking Scale. https://nursing.case.edu/nursing/media/nursing/pdf -dox/STS_Manual.pdf

Mueller S (2011). Increasing entrepreneurial intention: Effective entrepreneurship course characteristics. International Journal of Entrepreneurship and Small Business, 13, 55-74.
Nunnally J C \& Bernstein I H (1994). The Assessment of Reliability. Psychometric Theory, 3, 248-292.

Orgill M, York S \& MacKellar J (2019). Introduction to systems thinking for the chemistry education community. Journal of Chemical Education 201996 (12), 2720-2729, DOI: 10.1021/acs.jchemed.9b00169

Pagani M \& Otto P (2013). Integrating strategic thinking and simulation in marketing strategy: Seeing the whole System. Journal of Business Research, 66, 15681575

Pappas E, Pierrakos 0 \& Nagel R (2012). Using Bloom's Taxonomy to teach sustainability in multiple contexts. Journal of Cleaner Production, 48, 54-64.

Patel S \& Mehta K (2016). Systems, design, and entrepreneurial thinking: Comparative frameworks. Systemic Practice and Action Research, ISSN 1094429X, 29(6), DOI 10.1007/s11213-016-9404-5

Patır S \& Karahan M (2010). Girişimcilik eğitimi ve üniversite öğrencilerinin girişimcilik profillerinin belirlenmesine yönelik bir alan araștırması. İșletme ve Ekonomi Araştırmaları Dergisi. 1 (2), 27-44.

Rayawan W \& Efrata T C (2017). The effect locus of control and need for achievement towards entrepreneurial performance. Review Management Entrepreneurship, 1, 36-49.

Saaty T L (2008). Decision making with the analytic hierarchy process. International Journal of Service Sciences 1(1), 83-98

Sadler T D \& Zeidler D L (2005). The significance of content knowledge for informal reasoning regarding socioscientific issues: Applying genetics knowledge to genetic engineering issues. Science Education, 89(1), 71-93.

Solomon J \& Aikenhead G S (Eds.). (1994). STS education: International perspectives on reform. New York: Teachers College Press

Thunholm P (2009). Military leaders and followers - do they have different decision styles? Scandinavian Journal of Psychology, 50(4), 317-324

Verhoeff R P, Waarlo A J \& Boersma K T (2008) Systems modeling and the development of coherent understanding of cell biology. International Journal of Science Education, 30, 543-568

Yesilyaprak B (2003). Eğitimde rehberlik hizmetleri ve gelişimsel yaklaşım. Ankara: Nobel Yayincilik.

Zeidler D L, Sadler T D, Applebaum S \& Callahan B E (2009). Advancing reflective judgment through socioscientific issues. Journal of Research in Science Teaching, 46(1), 74-101. 